Prepared in collaboration with Abraxis, LLC, Delaware Department of Natural Resources and Environmental Control Division of Water Resources Environmental Laboratory, and the University of Delaware

Comparison of Two Gell Lysis Procedures for Recovery of Microcystins in Water Samples from Silver Lake in Dover, Delaware, with Microcystin Producing Cyanobacterial Accumulations

\title{
.
}

The

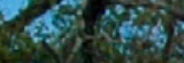

costos

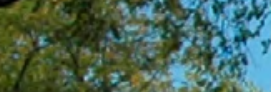

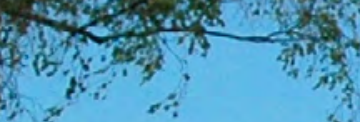

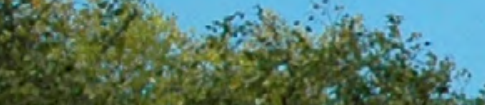

1.7.

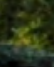

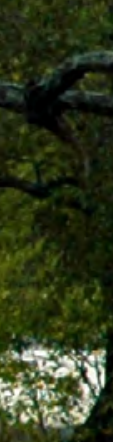

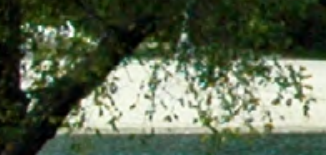

Open-File Report 2008-1341

U.S. Department of the Interior

U.S. Geological Survey 
Front cover. Absence of cyanobacterial accumulation in Silver Lake, Dover, Delaware, September 2006 (photograph taken by J. Scott Figurski, Delaware Department of Natural Resources and Environmental Control-Wetlands). 


\section{Comparison of Two Cell Lysis Procedures for Recovery of Microcystins in Water Samples from Silver Lake in Dover, Delaware, with Microcystin Producing Cyanobacterial Accumulations}

By Keith A. Loftin, Michael T. Meyer, Fernando Rubio, Lisa Kamp, Edythe Humphries, and Ed Whereat

Prepared in collaboration with Abraxis, LLC, Delaware Department of Natural

Resources and Environmental Control Division of Water Resources Environmental Laboratory, and the University of Delaware

Open-File Report 2008-1341 


\section{U.S. Department of the Interior DIRK KEMPTHORNE, Secretary}

\section{U.S. Geological Survey \\ Mark D. Myers, Director}

\section{U.S. Geological Survey, Reston, Virginia: 2008}

For product and ordering information:

World Wide Web: http://www.usgs.gov/pubprod

Telephone: 1-888-ASK-USGS

For more information on the USGS — the Federal source for science about the Earth, its natural and living resources, natural hazards, and the environment:

World Wide Web: http://www.usgs.gov

Telephone: 1-888-ASK-USGS

Any use of trade, product, or firm names is for descriptive purposes only and does not imply endorsement by the U.S. Government.

Although this report is in the public domain, permission must be secured from the individual copyright owners to reproduce any copyrighted materials contained within this report.

Suggested citation:

Loftin, K. A., Meyer, M.T., Rubio, F., Kamp, L., Humphries, E., Whereat, E., 2008, Comparison of two cell lysis procedures for recovery of microcystins in water samples from Silver Lake in Dover, Delaware with microcystin producing cyanobacterial accumulations: USGS Open-File Report 2008-1341, 9 p. 


\section{Contents}

Abstract

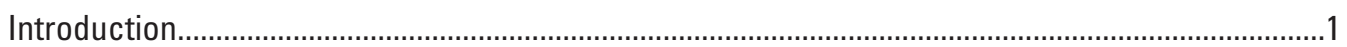

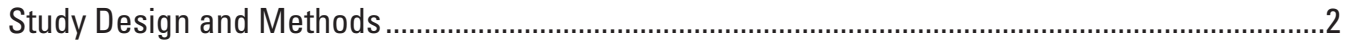

Calibration Solutions for Liquid Chromatography Tandem Mass Spectrometry (LC/MS/MS).2

Sampling Site and Collection Procedure ..............................................................................

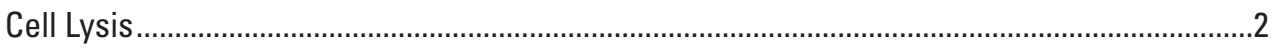

Identification and Cell Count Approximation of Potential Toxin Producing Cyanobacteria.....4

Analytical Methods.......................................................................................................

Monoclonal Enzyme Linked Immunosorbent Assay for Microcystins and Nodularins ...4

Liquid Chromatography Tandem Mass Spectrometry for Cyanotoxins .............................5

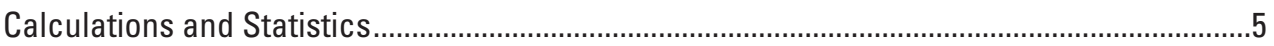

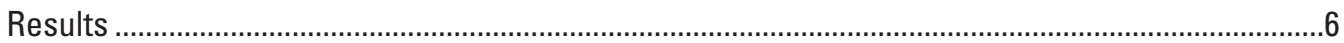

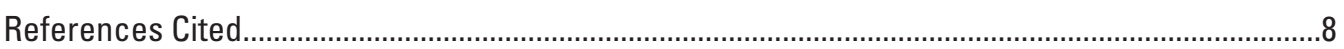

\section{Tables}

1. Compounds and liquid chromatography/tandem mass spectrometry (LC/MS/MS) tran-

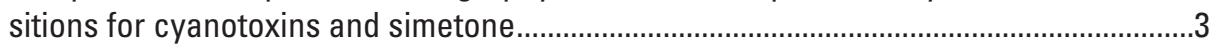

2. Percent cross reactivity of several microcystins and nodularin- $R$ for Abraxis monoclonal microcystins and nodularins enzyme-linked immunosorbent assay...........................5

3. Liquid chromatography/tandem mass spectrometry (LC/MS/MS) gradient for separation of cyanotoxins ......................................................................................................

4. Cyanotoxin concentrations by liquid chromatography/tandem mass spectrometry (LC/MS/MS)

5. Cross-reactivity corrected liquid chromatography/tandem mass spectrometry (LC/MS/MS) microcystin concentrations

6. Statistical summary of microcystin recovery for samples processed by QuikLyse ${ }^{\mathrm{TM}}$ and sequential freeze/thaw procedures. 
Conversion Factors

\begin{tabular}{lll}
\hline \multicolumn{1}{c}{ Multiply } & \multicolumn{1}{c}{ By } & \multicolumn{1}{c}{ To obtain } \\
\hline micrometer $(\mu \mathrm{m})$ & Length & \\
millimeter $(\mathrm{mm})$ & $3.937 \times 10^{-5}$ & inch (in.) \\
\hline & 0.03937 & inch (in.) \\
\hline liter $(\mathrm{L})$ & Volume & \\
milliliter $(\mathrm{mL})$ & 0.2642 & gallon $(\mathrm{gal})$ \\
microliter $(\mu \mathrm{L})$ & $2.642 \times 10^{-4}$ & gallon $(\mathrm{gal})$ \\
microgram per milliliter $(\mu \mathrm{g} / \mathrm{mL})$ & $2.642 \times 10^{-7}$ & gallon $(\mathrm{gal})$ \\
microgram per Liter $(\mu \mathrm{g} / \mathrm{L})$ & 1.0 & part per million $(\mathrm{ppm})$ \\
\hline
\end{tabular}

Temperature in degrees Celsius $\left({ }^{\circ} \mathrm{C}\right)$ may be converted to degrees Fahrenheit $\left({ }^{\circ} \mathrm{F}\right)$ as follows: ${ }^{\circ} \mathrm{F}=\left(1.8 \mathrm{x}^{\circ} \mathrm{C}\right)+32$

Temperature in degrees Fahrenheit $\left({ }^{\circ} \mathrm{F}\right)$ may be converted to degrees Celsius $\left({ }^{\circ} \mathrm{C}\right)$ as follows:

${ }^{\circ} \mathrm{C}=\left({ }^{\circ} \mathrm{F}-32\right) / 1.8$

\title{
Abbreviated Water-Quality Units
}

\author{
gram $(\mathrm{g})$ \\ microgram per liter $(\mu \mathrm{g} / \mathrm{L})$ \\ microgram per milliliter $(\mu \mathrm{g} / \mathrm{mL})$ \\ microliter per minute $(\mu \mathrm{L} / \mathrm{min})$ \\ milligram per milliliter $(\mathrm{mg} / \mathrm{mL})$ \\ milliliter $(\mathrm{mL})$ \\ milliliter per minute $(\mathrm{mL} / \mathrm{min})$ \\ cells per milliliter (cells $/ \mathrm{mL}$ )
}




\title{
Other Abbreviations Used in This Report
}

\author{
$\pm$ \\ PRSD \\ plus or minus \\ $\alpha$ \\ percent relative standard deviation \\ CAS \\ CI \\ alpha, the statistical probability of a type I error \\ Chemical Abstracts Service \\ confidence interval at a defined type I error level $(\alpha)$ \\ Delaware DNRECDWREL \\ State of Delaware Department of Natural Resources and Environmental \\ Control Division of Water Resources Environmental Laboratory \\ ELISA \\ enzyme-linked immunosorbent assay \\ ES+ \\ Electrospray Positive Ionization \\ ES- \\ Electrospray Negative Ionization \\ ISTD \\ internal standard \\ $\mathrm{LC} / \mathrm{MS} / \mathrm{MS}$ \\ liquid chromatography/tandem mass spectrometry \\ MRM \\ $\mathrm{n}$ \\ multiple reaction monitoring \\ a statistical nomenclature used to represent the number of \\ measurements \\ OGRL \\ Organic Geochemistry Research Laboratory, USGS \\ Q \\ Quantifying MRM transition \\ $s p$. \\ when used in conjunction with a cyanobacterial genus name, $s p$. is a \\ generic designation for all species within a given genus (for example, \\ Anabaena sp.) \\ USGS \\ U.S. Geological Survey \\ $\mathrm{v} / \mathrm{v}$ \\ volume-to-volume
}





\title{
Comparison of Two Cell Lysis Procedures for Recovery of Microcystins in Water Samples from Silver Lake in Dover, Delaware with Microcystin Producing Cyanobacterial Accumulations
}

\author{
By Keith A. Loftin, Michael T. Meyer, Fernando Rubio, Lisa Kamp, Edythe Humphries, and Ed Whereat
}

\begin{abstract}
A collaboration was developed between Abraxis, LLC, the State of Delaware Department of Natural Resources and Environmental Control Division of Water Resources Environmental Laboratory, the University of Delaware, and the United States Geological Survey to investigate the efficacy of the QuikLyse ${ }^{\mathrm{TM}}$ procedure developed by Abraxis, LLC as an alternative cell-lysis technique suitable for use with an existing liquid chromatography/tandem mass spectrometry research method developed at the United States Geological Survey Organic Geochemistry Research Laboratory to analyze cyanotoxins. A comparison of three sequential freeze/thaw cycles versus QuikLyse ${ }^{\mathrm{TM}}$, a proprietary chemical lysis procedure was conducted on four water samples collected from Silver Lake in Dover, Delaware. Results from the Abraxis Microcystins-DM enzyme-linked immunosorbent assay and liquid chromatography/tandem mass spectrometry were tabulated as a function of the cell lysis technique. Stastical comparison of percent relative standard deviations showed no significant difference $(\alpha=0.05)$ between both cell-lysis techniques when measured by enzyme-linked immunosorbent assay or liquid chromatography/tandem mass spectrometry for three of the four samples.
\end{abstract}

\section{Introduction}

Cyanobacterial blooms and accumulations in surface waters have long been viewed as an environmental and aesthetic problem because of the effects they have had on dissolved oxygen in surface water, leading to fish kills, and odor issues. The discovery of toxin production in cyanobacteria however, created an elevated level of concern for human and ecological health (Chorus and Bartram, 1999). One of the more commonly occurring classes of cyanotoxins are the microcystins, which are cyclic heptapeptides, produced by several cyanobacterial species, including Anabaena sp. and Microcystis sp. Microcystins are believed to be produced and maintained intracellularly throughout the cyanobacterial growth cycle and released upon cell death or perhaps even leaking out of the cell as apoptosis is approached (Chorus and Bartram, 1999). Generally, exposure to microcystins in humans or animals can occur by several pathways including consumption of raw or inadequately treated water, consumption of organisms with accumulated toxins, aerosols, and direct skin contact (Dawson, 1998; Milutinović and others, 2003; Orr and others, 2003; Orr and others, 2001; Jacquet and others, 2004; Li and others, 2004; Benson and others, 2005; Chorus and Bartram, 1999). As a result of the various pathways of exposure and the variability observed in toxin dose depending on the life cycle of the cyanobacterial bloom, it may be important to measure dissolved and total toxin concentrations. Dissolved-phase toxin concentrations indicate the available toxin present in the aqeous-phase. Total toxin concentrations indicate the maximum exposure one is likely to encounter under those sampling conditions. When total toxin and dissolved toxin concentrations are evaluated together, information can be obtained regarding the status of the cyanobacterial bloom life cycle. For example, if total toxin concentrations agree with dissolved-phase toxin concentrations, this might indicate that the bloom has undergone senescence and already has released all toxin into the dissolved-phase; however, in the opposite scenario where dissolved-phase concentrations are much lower or not measureable compared to total toxin concentrations, this might indicate that the bloom was in its earlier stages of life. Therefore, it is advantageous to have the ability to quantitatively measure dissolved and total toxin concentrations where it is necessary to have a viable cell-lysis technique in the laboratory setting to obtain the total toxin results (Graham and others, 2008).

Rapid results in certain cases are strongly desired by state and local decision makers with responsibily for beach and/ or lake closures to protect public health. In the absence of reliable toxin data, officials are compelled to make unsubstantiated decisions that must strike a socially acceptable balance between public health if recreational areas are left open during 
toxic bloom events and lost tourism revenue if they are closed. Portable enzyme-linked immunosorbent assays (ELISA) have been developed during the last few years that reduce the time to achieve these results; however, until recently (2008) ELISAs were not equipped to analyze the total toxin concentration because cell-lysis techniques are not transferred easily to the field.

Several techniques previously have been used in the laboratory, including successive freeze-thaw cycles, autoclavation, sonication, boiling, and solvent extraction (Chorus and Bartram, 1999; Lahti and others, 1997; Fastner and others, 1998; Tsuji and others, 1994; Lawton and others, 1995; Spoof and others, 2003; Barco and others, 2005; Dahlmann and others, 2003). Drawbacks to most of these techniques, except solvent extraction, are that most of them are not readily amenable for use in the field and take a significant amount of sample processing time; however recently (2008), a proprietary set of reagents called QuikLyse ${ }^{\mathrm{TM}}$, was developed and introduced by Abraxis, LLC (Warminster, PA) for cell-lysis of cyanobacteria and is packaged with their ELISA for microcystin and nodularin analysis in the 96-well plate format and a portable ELISA for field use. Decision makers frequently want more information about their systems to aid them in future decisions and, therefore, may desire to know which microcystin variants were present since they vary in toxicity. Whereas ELISA is useful as a quantitative screening tool, specificity is gained through the use of techniques such as liquid chromatography/ tandem mass spectrometry (LC/MS/MS).

The U.S. Geological Survey Organic Geochemistry Research Laboratory (OGRL) routinely conducts microcystin ELISA and LC/MS/MS on samples for cyanotoxin analyses. Since cell-lysis frequently is a rate limiting step in the duration a toxin sample may spend in a laboratory before results are available, it was desirable to investigate the effects the QuikLyse reagents ${ }^{\mathrm{TM}}$ might have on LC/MS/MS analyses. Since data interpretation can be affected by the cell lysis procedure used, a comparison of the existing cell lysis procedure (sequential freeze/thaw) used at the OGRL versus the QuikLyse reagent ${ }^{\mathrm{TM}}$ was conducted to assess if the QuikLyse ${ }^{\mathrm{TM}}$ procedure might be worth further investigation as a replacement to the time intensive sequential freeze/thaw process. Samples were collected by the State of Delaware Department of Natural Resources and Environmental Control Division of Water Resources Environmental Laboratory (Delaware DNRECDWREL) from Silver Lake in Dover, Delaware. Potential cyanotoxin producers were identified and cell counts conducted at the University of Delaware as a secondary objective on samples collected in the vicinity and at the same time as the toxin samples. All samples were homogenized and split at the OGRL. Cell lysis and ELISA were conducted at Abraxis, LLC using the QuikLyse ${ }^{\mathrm{TM}}$ reagents and the Microcystin-DM kit. Lysed samples were analyzed by LC/MS/MS at the OGRL.

\section{Study Design and Methods}

\section{Calibration Solutions for Liquid Chromatography Tandem Mass Spectrometry (LC/MS/MS)}

For cyantoxin standards, Anatoxin-a (ANAA) was obtained from A.G. Scientific (San Diego, CA). Domoic acid (DMAC), lyngbyatoxin-A (LYGA), microcystins -LA (MCLA), -LF (MCLF), -LR (MCLR), -LW (MCLW), -RR (MCRR), and okadaic acid (OKAC) were obtained from Calbiochem (Darmstadt, Germany). Microcystins -YR was obtained from Sigma-Aldrich (St. Louis, MO). Microcystin-LY was obtained from Alexis (San Diego, CA), and cylindrospermopsin (CYLS), deoxycylindrospermopsin (DCYL), and Nodularin-R (NODR) were obtained from Abraxis, LLC (Warminster, PA). Two letter designations used after the word microcystin or one letter designations after nodularin are abbreviations used for the pertinent amino acid subsititution on the cyclic part of these molecules. Cyanotoxins standards were used as received, treated as 100 percent pure, and diluted to 100 micrograms per milliliter $(\mu \mathrm{g} / \mathrm{mL})$ in LC/MS grade methanol (Burdick and Jackson, Morristown, NJ). Simetone was used as an internal standard and was obtained from ChemService (West Chester, PA). A list of the toxins studied and their abbreviations is given in table 1 .

\section{Sampling Site and Collection Procedure}

Four water samples with an observable cyanobacterial accumulation were collected by the State of Delaware Department of Natural Resources and Environmental Control Division of Water Resources Evironmental Laboratory (Delaware DNRECDWREL) on September 13, 2007, at Silver Lake (39.1741 degrees north, -75.5286 degrees west) in Dover, Delaware. Grab samples were collected in 2 liter (L) polypropylene containers and shipped on ice overnight to minimize cell lysis (Graham and others, 2008). Homogenized aliquots in 250 milliliter $(\mathrm{mL})$ amber glass bottles were shipped on ice overnight to Abraxis, LLC.

\section{Cell Lysis}

Each sample was homogenized, split, and lysed by one of two techniques, sequential freeze/thaw (Chorus and Bartram, 1999, Graham and others, 2008, Sangolkar and others, 2006) or the Abraxis QuikLyse ${ }^{\mathrm{TM}}$ reagents. Sample aliquots were divided into two, $40-\mathrm{mL}$ glass vials with Teflon lined caps, one for each cell-lysis technique.

Aliqouts processed by the sequential freeze/thaw procedure were placed in a freezer $\left(-20^{\circ} \mathrm{C}\right.$ (degrees Celsius) until frozen and then thawed at room temperature (approximately $25^{\circ} \mathrm{C}$ ) in the absence of light. This process was repeated two additional times for a total of three complete cycles. 
Table 1. Compounds and liquid chromatography/tandem mass spectrometry (LC/MS/MS) transitions for cyanotoxins and simetone.

[CAS, Chemical Abstract Service number; ES+, Electrospray Positive Mode; ES-, Electrospray Negative Mode; EM, Exact mass calculated by ChemDraw Ultra 9.0.1, CambridgeSoft, Inc.; ISTD, Internal Standard, MRM, Multiple Reaction Monitoring, No CAS was available; Q, Quantifying MRM transition; -, no additional data]

\begin{tabular}{|c|c|c|c|c|c|}
\hline Compound & Abbreviation & Ionization mode & MRM Transition & $\begin{array}{l}\text { MRM } \\
\text { ratio }^{1}\end{array}$ & $\begin{array}{l}\text { Retention time } \\
\text { (minutes) }\end{array}$ \\
\hline $\begin{array}{c}\text { Anatoxin-A } \\
\text { CAS [64285-06-9] } \\
\text { EM: } 166.12\end{array}$ & ANAA & $\mathrm{ES}+$ & $\begin{array}{c}166.0 / 90.9 \\
166.0 / 131.2 \\
166.0 / 148.9\end{array}$ & $\begin{array}{l}0.45 \\
.53 \\
Q\end{array}$ & $\overline{-}$ \\
\hline \multirow[t]{2}{*}{$\begin{array}{l}\text { Cylindrospermopsin } \\
\text { CAS [14345-90-8] } \\
\text { EM: } 415.12\end{array}$} & CYLS & $\mathrm{ES}+$ & $\begin{array}{l}416.3 / 176.2 \\
416.3 / 194.2 \\
416.3 / 336.0\end{array}$ & $\begin{array}{l}.35 \\
.83 \\
.48\end{array}$ & - \\
\hline & & ES- & $\begin{array}{l}414.1 / 272.1 \\
414.1 / 302.2\end{array}$ & $\begin{array}{l}\mathrm{Q} \\
.18\end{array}$ & $\begin{array}{l}6.5 \\
-\end{array}$ \\
\hline $\begin{array}{c}\text { Deoxycylindrospermopsin } \\
\text { CAS [NA] } \\
\text { EM: } 399.12\end{array}$ & DCYL & $\mathrm{ES}+$ & $\begin{array}{l}400.4 / 176.1 \\
400.4 / 194.1\end{array}$ & $\begin{array}{l}.66 \\
Q\end{array}$ & $\overline{8.3}$ \\
\hline $\begin{array}{l}\text { Domoic Acid } \\
\text { CAS[14277-97-5] } \\
\text { EM: } 311.14\end{array}$ & DMAC & $\mathrm{ES}+$ & $\begin{array}{l}312.2 / 220.1 \\
312.2 / 266.2\end{array}$ & $\begin{array}{l}\mathrm{Q} \\
.19\end{array}$ & $\begin{array}{r}9.9 \\
-\end{array}$ \\
\hline $\begin{array}{l}\text { Lyngbyatoxin-a } \\
\text { CAS[70497-14-2] } \\
\text { EM: } 437.30\end{array}$ & LYGA & ES+ & 438.2 / 296.1 & Q & 18.3 \\
\hline $\begin{array}{l}\text { Microcystin-LA } \\
\text { CAS [96180-79-9] } \\
\text { EM: } 909.48\end{array}$ & MCLA & ES- & $\begin{array}{l}908.9 / 128.2 \\
908.9 / 890.8\end{array}$ & $\begin{array}{l}\mathrm{Q} \\
.72\end{array}$ & $\begin{array}{r}16.8 \\
-\end{array}$ \\
\hline $\begin{array}{l}\text { Microcystin-LF } \\
\text { CAS [154037-70-4] } \\
\text { EM: } 985.52\end{array}$ & MCLF & ES- & $\begin{array}{l}984.7 / 127.7 \\
984.7 / 966.5\end{array}$ & $\begin{array}{l}.26 \\
\mathrm{Q}\end{array}$ & 19.0 \\
\hline \multirow[t]{2}{*}{$\begin{array}{l}\text { Microcystin-LR } \\
\text { CAS [101043-37-2] } \\
\text { EM: } 994.55\end{array}$} & MCLR & $\mathrm{ES}+$ & $\begin{array}{l}995.7 / 135.2 \\
995.7 / 213.2\end{array}$ & $\begin{array}{l}.08 \\
.06\end{array}$ & - \\
\hline & & ES- & $\begin{array}{l}993.5 / 128.1 \\
993.6 / 975.8\end{array}$ & $\begin{array}{l}.61 \\
Q\end{array}$ & 13.3 \\
\hline $\begin{array}{l}\text { Microcystin-LW } \\
\text { CAS [157622-02-1] } \\
\text { EM: } 1024.53\end{array}$ & MCLW & ES- & $\begin{array}{c}1,023.5 / 128.0 \\
1,023.5 / 1,005.8\end{array}$ & $\begin{array}{c}.70 \\
Q\end{array}$ & 18.0 \\
\hline \multirow[t]{2}{*}{$\begin{array}{l}\text { Microcystin-LY } \\
\text { CAS [123304-10-9] } \\
\text { EM: } 1001.51\end{array}$} & MCLY & $\mathrm{ES}+$ & $\begin{array}{l}1,002.7 / 135.0 \\
1,002.7 / 984.8\end{array}$ & $\begin{array}{l}.13 \\
.06\end{array}$ & - \\
\hline & & ES- & $\begin{array}{l}1,000.7 / 128.1 \\
1,000.7 / 982.2\end{array}$ & $\begin{array}{l}.71 \\
\mathrm{Q}\end{array}$ & $-\overline{16.8}$ \\
\hline \multirow[t]{2}{*}{$\begin{array}{l}\text { Microcystin-RR } \\
\text { CAS [111755-37-4] } \\
\text { EM: } 1037.57\end{array}$} & MCRR & $\mathrm{ES}+$ & $\begin{array}{l}520.0 / 135.0 \\
520.0 / 213.2 \\
520.0 / 103.0\end{array}$ & $\begin{array}{l}\mathrm{Q} \\
.11 \\
.65\end{array}$ & $\begin{array}{r}11.8 \\
-\end{array}$ \\
\hline & & ES- & $\begin{array}{c}1,036.6 / 128.3 \\
1,036.6 / 1,018.6\end{array}$ & $\begin{array}{l}.08 \\
.24\end{array}$ & - \\
\hline \multirow{2}{*}{$\begin{array}{l}\text { Microcystin-YR } \\
\text { CAS [101064-48-6] } \\
\text { EM: } 1044.53\end{array}$} & MCYR & $\mathrm{ES}+$ & $\begin{array}{l}1,045.8 / 135.2 \\
1,045.8 / 213.0\end{array}$ & $\begin{array}{l}.09 \\
.06\end{array}$ & - \\
\hline & & ES- & $\begin{array}{c}1,043.7 / 128.2 \\
1,043.7 / 1,025.8\end{array}$ & $\begin{array}{l}.58 \\
\mathrm{Q}\end{array}$ & 12.9 \\
\hline
\end{tabular}


Table 1. Compounds and liquid chromatography/tandem mass spectrometry (LC/MS/MS) transitions for cyanotoxins and simetone.-Continued

[CAS, Chemical Abstract Service number; ES+, Electrospray Positive Mode; ES-, Electrospray Negative Mode; EM, Exact mass calculated by ChemDraw Ultra 9.0.1, CambridgeSoft, Inc.; ISTD, Internal Standard, MRM, Multiple Reaction Monitoring, No CAS was available; Q, Quantifying MRM transition; -, no additional data]

\begin{tabular}{cccccc}
\hline Compound & Abbreviation & lonization mode & MRM Transition & $\begin{array}{c}\text { MRM } \\
\text { ratio }\end{array}$ & $\begin{array}{c}\text { Retention time } \\
\text { (minutes) }\end{array}$ \\
\hline Nodularin-R & NODR & ES+ & $825.7 / 135.1$ & 0.25 & - \\
CAS[118399-22-7] & & & $825.7 / 227.2$ & .14 & - \\
EM: 824.44 & & ES- & $823.6 / 128.2$ & .33 & - \\
& & & $823.6 / 805.6$ & $\mathrm{Q}$ & 12.9 \\
& OKAC & ES- & $803.6 / 113.0$ & .48 & - \\
Okadaic Acid & & & $803.6 / 151.1$ & .19 & - \\
CAS[78111-17-8] & & $803.6 / 255.1$ & $\mathrm{Q}$ & 16.7 \\
EM: 804.47 & ES+ & $198.1 / 124.1$ & ISTD & 10.7 \\
Simetone & & & & \\
CAS[673-04-1] & & & & & \\
EM: 197.24 & & & & & \\
\hline
\end{tabular}

${ }^{1}$ MRM Ratio, this ratio is equal to the area ratio (analyte area/ internal standard area) of the quantifying transition to the confirming transition.

\begin{abstract}
Aliqouts $(1 \mathrm{~mL})$ processed by the QuikLyse ${ }^{\mathrm{TM}}$ reagents (Abraxis, LLC, 2008) were shaken for 2 minutes in vials containing QuikLyse ${ }^{\mathrm{TM}}$ reagent $\mathrm{A}$ followed by an 8 minute room temperature incubation. Reagent papers containing dried QuikLyse ${ }^{\mathrm{TM}}$ reagent B were then added and shaken for an additional 2 minutes followed by an additional 8 minute room temperature incubation. Samples lysed by both techniques were then filtered using the QuikLyse ${ }^{\mathrm{TM}}$ filtering system (Abraxis, LLC, Warminster, PA) where each sample was drawn into a disposable pipette followed by attachment of a filter tip. Samples were filtered dropwise into $4 \mathrm{~mL}$ clean glass vials (Abraxis QuikLyse ${ }^{\mathrm{TM}}$ reagent procedure) and analyzed immediately by the Abraxis Microcystins-DM ELISA. Aliqouts of samples lysed by both techniques also were shipped overnight to the OGRL on ice for LC/MS/MS analysis.

Standard safety protocols should be used when working with the QuikLyse ${ }^{\mathrm{TM}}$ reagents such as gloves and safety glasses. In case of skin contact, rinse exposed area thoroughly with water. Since the reagent is concentration dependent, the lysis rate decreases with decreasing reagent concentration.
\end{abstract}

\section{Identification and Cell Count Approximation of Potential Toxin Producing Cyanobacteria}

Microscopic identification and approximation of potential toxin producing bacteria was conducted at the University of Delaware. A near shore cove sample and and an offshore cove sample were screened the same day samples were collected using a standard microscope (American Optical Corp., model 60 ) and taxonomy according to Wehr and Sheath, 2003. Three 40 microliter $(\mu \mathrm{L})$ drops were placed on separate conventional microscope slides with coverslips. Cell density estimates were based on counting filaments or cell aggregates in ten random fields of view for each drop and reported as cells $/ \mathrm{mL}$ (Whereat and others, 2004). Magnification was at a $100 \mathrm{X}$ for Microcystis sp. and Cylindrospermopsis sp., and ranged from 100 to $450 \mathrm{X}$ for Anabaena sp. The depth of water under the cover slip was estimated at 80 micrometers $(\mu \mathrm{m})$.

\section{Analytical Methods}

Analyses of the split samples processed by both cell lysis techniques were evaluated by a microcystin-LR monoclonal enzyme linked immunosorbent assay (ELISA) at Abraxis, LLC and liquid chromatography tandem mass spectrometry (LC/MS/MS) for microcystins and nodularin-R at the USGS OGRL.

\section{Monoclonal Enzyme Linked Immunosorbent Assay for Microcystins and Nodularins}

Aliquots $(100 \mu \mathrm{L})$ of samples processed by both the QuikLyse $^{\mathrm{TM}}$ reagents and the freeze/thaw technique were analyzed by a monoclonal direct competitive ELISA (Abraxis, LLC, Microcystin ELISA-DM kit), Warminster, PA) with a calibration range 0.15 to 5 micrograms per liter $(\mu \mathrm{g} / \mathrm{L})$ based on a MCLR standard and a minimum detection level of $0.10 \mu \mathrm{g} / \mathrm{L}$. Manufacturer directions were followed for this analysis (Abraxis, LLC, 2007). The ELISA kit is known to be cross reactive with Microcystin LR (MCLR), Microcystin YR (MCYR), Microcystin RR (MCRR), Microcystin LA (MCLA), and Nodularin R (NODR) in addition to several 
other congeners (table 2), thus it is not possible to distinguish between the congeners by ELISA. As a result, all concentrations measured by this assay are reported as micrograms per liter $(\mu \mathrm{g} / \mathrm{L})$ of MCLR equivalents since the calibration curve is based on MCLR. Quantitation for ELISA was based on a four parameter curve fit of a MCLR standard curve (Abraxis Microcystins-DM ELISA Procedure, Abraxis, LLC, 2007).

\section{Liquid Chromatography Tandem Mass Spectrometry for Cyanotoxins}

An LC/MS/MS Cyanotoxin method was developed after Cong and others, 2006, Dahlman and others, 2003, and Dell' Aversano and others, 2004. Cyanotoxins (MCLA, MCLF, MCLR, MCLW, MCLY, MCRR, MCYR, and NODR) were separated on a Shimadzu Prominence liquid chromatograph (Kyoto, Japan) and detected with an Applied Biosystems API 5000 tandem mass spectrometer (Foster City, CA) in electrospray positive (ES+) and negative (ES-) modes. Source parameters were optimized for the entire suite of compounds (table 1). Compounds were separated by a reverse-phase gradient on a Waters Atlantis dC18 $3 \mu \mathrm{m}$ column [3.0 millimeters $(\mathrm{mm}) \times 150 \mathrm{~mm}$, Milford, MA] preceded by a Waters Atlantis $\mathrm{dC} 183 \mu \mathrm{m}$ guard cartridge ( $3.9 \mathrm{~mm} \times 20 \mathrm{~mm}$, Milford, MA). Mobile phases consisted of an aqueous 0.1 percent formic acid (mobile phase A) versus 100 percent methanol (mobile phase B) (table 3). The gradient separation shown in table 3 represents the percent mobile phase $\mathrm{B}$ used as a function of time with the balance of 100 percent being mobile phase A. Samples were quantitated by standard addition. Unspiked sample aliquots $(300 \mu \mathrm{L})$ were amended with $20 \mu \mathrm{L}$ of a $0.06 \mu \mathrm{g} / \mathrm{L}$

Table 2. Percent cross reactivity of several microcystins and nodularin- $R$ for Abraxis monoclonal microcystins and nodularins enzyme-linked immunosorbent assay (Abraxis, LLC, 2007).

\begin{tabular}{|c|c|}
\hline Cyanotoxin & Cross reactivity (weight/weight) ${ }^{1}$ \\
\hline Microcystin-LA (MCLA) & 48 \\
\hline Microcystin-LF (MCLF) & 72 \\
\hline Microcystin-LR (MCLR) & 100 \\
\hline Microcystin-LW (MCLW) & 102 \\
\hline Microcystin-LY (MCLY) & 273.6 \\
\hline Microcystin-RR (MCRR) & 53 \\
\hline Microcystin-YR (MCYR) & 64 \\
\hline Nodularin-R (NODR) & 76 \\
\hline \multicolumn{2}{|c|}{${ }^{1}$ Cross-reactivity was determined on a by weight basis. } \\
\hline $\begin{array}{l}{ }^{2} \mathrm{~A} \text { cross reactivity value for } \\
\text { value was estimated based on } \mathrm{t} \\
\text { reactivity values. }\end{array}$ & $\begin{array}{l}\text { LY was unavailable; therefore, this } \\
\text { verage of the other microcystin cross- }\end{array}$ \\
\hline
\end{tabular}

Table 3. Liquid chromatography/tandem mass spectrometry (LC/MS/MS) gradient for separation of cyanotoxins.

\begin{tabular}{cc}
\hline Time (minutes) & Percent Mobile Phase $\mathbf{B}^{1}$ \\
\hline 0.02 & 5 \\
3.50 & 5 \\
5.00 & 30 \\
8.00 & 60 \\
15.00 & 95 \\
20.00 & 95 \\
20.01 & 5 \\
25.00 & 5 \\
\hline
\end{tabular}

\footnotetext{
${ }^{1}$ Percent Mobile Phase B is the percent of the organic mobile phase by volume used in the chromatographic gradient for separation of cyanotoxins in contrast to percent Mobile Phase A, which is the aqueous mobile phase.
}

aqueous solution of simetone (ISTD) in amber sample vials with glass microinserts (Wheaton, Millville, NJ) and spiked sample aliquots $(300 \mu \mathrm{L})$ were amended with $20 \mu \mathrm{L}$ of a $30 \mu \mathrm{g} / \mathrm{L}$ solution containing MCLA, MCLF, MCLR, MCLW, MCLY, MCRR, MCYR, NODR, and $0.06 \mu \mathrm{g} / \mathrm{L}$ Simetone (ISTD) yielding a $1.0 \mu \mathrm{g} / \mathrm{L}$ final spike concentration for the standard addition sample.

\section{Calculations and Statistics}

Concentrations for ELISA and LC/MS/MS were corrected for dilution where the QuikLyse ${ }^{\mathrm{TM}}$ reagent was utilized by multiplying by a factor of 1.11 (Abraxis QuikLyse ${ }^{\mathrm{TM}}$ reagent procedure, Abraxis, LLC 2008).

Direct comparison of ELISA and LC/MS/MS toxin concentrations are not recommended without a conversion of the LC/MS/MS data based on cross-reactivity of the detected congeners before summing concentrations from all congeners. Therefore, individual LC/MS/MS microcystin and nodularin congener concentrations were converted from $\mu \mathrm{g} / \mathrm{L}$ of the given congener to $\mu \mathrm{g} / \mathrm{L}$ of microcystin-LR equivalents based on:

$$
\mathrm{C}_{\text {MC-LR Equiv. MCXY }}=\mathrm{C}_{\text {MCXY }} \mathrm{CR}_{\mathrm{MCXY}}
$$

where:

$$
\begin{aligned}
\mathrm{C}_{\text {MCLR Equiv. MCXY }}= & \text { A MCLR equivalent LC/MS/MS } \\
& \text { concentration for a generic congener, } \\
& \text { MCXY }(\mu \mathrm{g} / \mathrm{L} \text { of microcystin-LR } \\
& \text { equivalents) that is corrected for cross- } \\
& \text { reactivity of the ELISA } \\
= & \text { LC/MS } / \mathrm{MS} \text { uncorrected concentration } \\
& \text { for a generic congener, MCXZ }(\mu \mathrm{g} / \mathrm{L} \text { of } \\
& \text { MCXZ equivalents })
\end{aligned}
$$




$$
\begin{aligned}
& \mathrm{CR}_{\text {MCXY }}=\text { Mass based ELISA cross-reactivity } \\
& \text { for MCXZ ( } \mu \mathrm{g} / \mathrm{L} \text { of microcystin-LR } \\
& \text { equivalents) }
\end{aligned}
$$

Since a cross-reactivity value for MCLY was unavailable for the monoclonal ELISA, the cross-reactivities for MCLA, MCLF, MCLR, MCLW, MCRR, and MCYR were averaged and a value of 73.6 was used (table 2). $C_{\text {MCLR Equiv. MCXZ }}$ values were then summed using the following equation:

$$
\begin{aligned}
& \mathrm{C}_{\mathrm{SMC}}=\Sigma\left(\mathrm{C}_{\text {MC-LR Equiv. MCXZ }}\right)_{i} \\
& \mathrm{C}_{\mathrm{SMC}}=\text { the summed MCLR equivalent } \\
& \text { concentration for each microcystin and } \\
& \text { nodularin congener measured by LC/MS/ } \\
& \text { MS ( } \mu \mathrm{g} / \mathrm{L} \text { of microcystin-LR equivalents) }
\end{aligned}
$$

Means and standard deviations (n-1 method) were calculated using Excel functions (AVERAGE and STDEV) (Microsoft Office 2007, Microsoft Corp., 2006), but confidence intervals were not since Excel assumes a $t$ value from an infinite number of $\mathrm{n}$ values (samples). Two-sided Student's $\mathrm{t}$-values were used to calculate 95 percent confidence intervals $(\alpha=0.05)$ (Skoog and others, 1996).

\section{Results}

Three potential toxin producing cyanobacteria were identified in the near shore and offshore cove samples and both samples were dominated by Anabaena sp. at 87.4 percent and 96.2 percent, respectively. Microcystis $s p$. was estimated at 9.1 percent and 2.5 percent and Cylindrospermospis sp. at 3.5 percent and 1.3 percent in the nearshore and offshore cove samples, respectively. Total cell volumes for these three genera were estimated at $8.2 \mathrm{E} 6$ and $1.0 \mathrm{E} 7$ cells $/ \mathrm{mL}$ in the nearshore and offshore cove samples, respectively. Potential toxin producing cyanobacteria identification is useful in conjunction with toxin quantitation to determine if a particular species is insensitive to a particular cell lysis technique.

Microcystins were detected in all samples regardless of cell lysis technique or analytical method. Uncorrected and cross-reactivity corrected microcystin congener concentrations measured by LC/MS/MS are shown in tables 4 and 5 . When microcystin congeners were detected in sample aliquots processed by the freeze/thaw technique, the same congeners also were detected in sample aliquots processed with the QuikLyse $^{\mathrm{TM}}$ reagents. Of the seven microcystin congeners measured by LC/MS/MS, at least two microcystins were measured in all samples with up to five microcystins of the seven measured in one sample. Specifically, two microcystins

\begin{tabular}{|c|c|c|c|c|c|}
\hline \multirow{2}{*}{ Site location } & \multicolumn{5}{|c|}{ Concentrations, in micrograms per liter } \\
\hline & MCLF & MCLR & MCLY & MCRR & MCYR \\
\hline \multicolumn{6}{|l|}{ Cove 2} \\
\hline QuikLyse & $>0.010$ & 1.8 & $>0.010$ & 1.7 & $>0.010$ \\
\hline Freeze/Thaw & $>.010$ & 1.3 & $>.010$ & 1.2 & $>.010$ \\
\hline \multicolumn{6}{|l|}{ Cove Offshore 6} \\
\hline QuikLyse $^{\mathrm{TM}}$ & .10 & 3.8 & .53 & 6.1 & .093 \\
\hline Freeze/Thaw & .079 & 4.7 & .40 & 3.8 & .087 \\
\hline \multicolumn{6}{|l|}{ Cove Offshore 7} \\
\hline QuikLyse $^{\mathrm{TM}}$ & .34 & 21 & $>.010$ & 15 & .68 \\
\hline Freeze/Thaw & .25 & 26 & $>.010$ & 16 & .58 \\
\hline \multicolumn{6}{|l|}{ Spillway 4} \\
\hline QuikLyse & $>.010$ & 3.2 & $>.010$ & .72 & $>.010$ \\
\hline Freeze/Thaw & $>.010$ & 2.5 & $>.010$ & .60 & $>.010$ \\
\hline
\end{tabular}
were detected in the Cove Offshore 2 sample and Spillway 4
Table 4. Cyanotoxin concentrations by liquid chromatography/ tandem mass spectrometry (LC/MS/MS).

[MCLF, microcystin-LF; MCLR, microcystin-LR; MCLY, microcystin-LY; MCRR, microcystin-RR; MCYR, microcystin-YR; > 0.10, indicates that value is less than the estimated minimum reporting level of 0.010 micrograms per liter]

Table 5. Cross-reactivity corrected liquid chromatography/ tandem mass spectrometry (LC/MS/MS) microcystin concentrations.

[MCLF, microcystin LF; MCLR, microcystin LR; MCLY, microcystin LY; MCRR, microcystin RR; MCYR, microcystin YR; > 0.10 , indicates that value is less than the estimated minimum reporting level of 0.010 micrograms per liter]

\begin{tabular}{lccccc}
\hline & \multicolumn{5}{c}{ Concentrations, in micrograms per liter } \\
\cline { 2 - 6 } \multicolumn{1}{c}{ Site location } & MCLF & MCLR & MCLY & MCRR & MCYR \\
\cline { 2 - 6 } & & & & & \\
\hline Cove 2 & & & & \\
QuikLyse & & & & & \\
Freeze/Thaw & $>010$ & 1.8 & $>0.010$ & 0.88 & $>0.010$ \\
Cove Offshore 6 & & 1.3 & $>.010$ & .62 & $>.010$ \\
QuikLyse & .073 & 3.9 & .39 & 3.2 & .059 \\
Freeze/Thaw & .057 & 4.7 & .29 & 2.0 & .056 \\
Cove Offshore 7 & & & & & \\
QuikLyse & .24 & 21 & $>.010$ & 8.2 & .43 \\
Freeze/Thaw & .18 & 26 & $>.010$ & 8.3 & .37 \\
Spillway 4 & & & & & \\
QuikLyse & $>.010$ & 3.2 & $>.010$ & .38 & $>.010$ \\
Freeze/Thaw & $>.010$ & 2.5 & $>.010$ & .32 & $>.010$ \\
\hline
\end{tabular}


sample, four microcystins in Cove Offshore 7, and 5 microcystins in Cove Offshore 6. MCLR and MCRR were detected in all four samples, whereas MCLF and MCYR were detected only in two samples, Cove Offshore 7 and Spillway 4. MCLY was detected only in Cove Offshore 7. ANAA, CYLS, DCYL, DMAC, LYGA, MCLA, MCLW, NODR, and OKAC were not detected by LC/MS/MS in any sample.

The sum of cross-reactivity corrected LC/MS/MS concentrations (eq. 1 and 2) and the monoclonal ELISA concentrations followed by percent relative standard deviations comparing the two cell-lysis techniques where toxins were measured by ELISA, LC/MS/MS, and a comparison of results between both analytical techniques, ELISA and LC/MS/MS are shown in table 6 . Summary statistics are included at the bottom of table 6 for each comparison. The grand mean of percent relative standard deviations, standard deviations, and 95-percent confidence intervals for all four samples within each comparison are shown at the bottom of table 6. Statistically, there was not a significant difference $(\alpha=0.05)$ in percent relative standard deviation (PRSD) values between the QuikLyse ${ }^{\mathrm{TM}}$ procedure and the freeze/thaw procedure when analyzed by ELISA for the samples from Cove 2, Cove Offshore 6, and Cove Offshore 7 where the grand mean PRSD for this comparison was $8.3 \pm 1.7 \%$. When this same comparison is applied to the summed LC/MS/MS cross-reactivity corrected data $\left(\mathrm{C}_{\mathrm{smc}}\right)$, no significant difference $(\alpha=0.05)$ in PRSD values between the QuikLyse ${ }^{\mathrm{TM}}$ procedure and the freeze/thaw procedure were observed for Cove Offshore 6, Cove Offshore 7, and Spillway 4 where the grand mean PRSD for this comparison was $14 \pm 7.5$ percent. A comparison of PRSD values for the $\mathrm{C}_{\mathrm{SMC}}$ and ELISA values for each sample and each cell-lysis technique showed a grand mean PRSD of $31 \pm 5.6$ percent. There was one sample outside of the confidence interval of the Grand Mean PRSD for each of these three comparisons: Spillway 4 PRSD ELISA), Cove 2 PRSD LC/MS/MS), and Cove 2 PRSD comparison of LC/MS/MS versus ELISA), respectively. More samples of varying toxin mixtures and concentrations, cyanobacterial cell volumes, and cyanobacterial species should be assessed to determine technique robustness.

Table 6. Statistical summary of microcystin recovery for samples processed by QuikLyse ${ }^{\mathrm{TM}}$ and sequential freeze/thaw procedures.

[ $\mu \mathrm{g} / \mathrm{L}$, microgram per liter; MCLR, microcystin-LR; LC/MS/MS, liquid chromatography/tandem mass spectrometry; ELISA, enzyme-linked immunosorbent assay; PRSD, percent relative standard deviation; - , no additional data]

\begin{tabular}{|c|c|c|c|c|c|}
\hline \multirow{2}{*}{ Site location } & \multicolumn{2}{|c|}{$\begin{array}{l}\text { Total microcystin concentration as } \mu \mathrm{g} / \mathrm{L} \text { of } \\
\text { MCLR equivalents }\end{array}$} & \multirow{2}{*}{$\begin{array}{c}\text { PRSD between } \\
\text { QuikLyse }{ }^{\mathrm{TM}} \text { and } \\
\text { freeze-thaw (ELISA) }\end{array}$} & \multirow{2}{*}{$\begin{array}{l}\text { PRSD between } \\
\text { QuikLyse }{ }^{\mathrm{TM}} \text { and } \\
\text { freeze-thaw } \\
\text { (LC/MS/MS) }\end{array}$} & \multirow{2}{*}{$\begin{array}{l}\text { PRSD between } \\
\text { LC/MS/MS and } \\
\text { ELISA data }\end{array}$} \\
\hline & $\begin{array}{l}\text { LC/MS/MS } \\
\left(C_{\text {sMc }}\right)^{1}\end{array}$ & Monoclonal ELISA & & & \\
\hline \multicolumn{6}{|l|}{ Cove 2} \\
\hline QuikLyse $^{\mathrm{TM}}$ & 2.7 & 1.4 & 7.0 & 25 & 45 \\
\hline QuikLyse & 7.6 & 4.9 & 8.8 & 4.7 & 30 \\
\hline Freeze/Thaw & 7.1 & 4.3 & - & - & 34 \\
\hline \multicolumn{6}{|l|}{ Cove Offshore 7} \\
\hline QuikLyse & 30 & 21 & 6.6 & 9.5 & 24 \\
\hline Freeze/Thaw & 34 & 23 & - & - & 27 \\
\hline $\mathrm{n}^{2}$ & & & 4 & 4 & 8 \\
\hline Grand Mean & & & 8.3 & 14 & 31 \\
\hline Standard Deviation & & & 2.0 & 9.0 & 6.7 \\
\hline Confidence Interval $^{3}$ & & & 1.7 & 7.5 & 5.6 \\
\hline
\end{tabular}




\section{References Cited}

Abraxis, LLC, 2007, Microcystins-DM ELISA (Microtiter Plate) enzyme-linked immunosorbent assay for the determination of microcystins and nodularins in water samples, Product No. 522015, accessed May 2008 at http://www. abraxiskits.com/moreinfo/PN522015USER.pdt

Abraxis, LLC, 2008, QuikLyse ${ }^{\mathrm{TM}}$ cell lysis for microcystins/ nodularins ELISA microtiter plate, Product No. 529911QL, accessed May 2008 at http://www.abraxiskits.com/moreinfo/ PN5229911.pdf

Barco, M., Lawton, L.A., Rivera, J., and Caixach, J., 2005, Optimization of intracellular microcystin extraction for their subsequent analysis by high-performance liquid chromatography: Journal of Chromatography A, v. 1074, p. 23-30.

Benson, J.M., Hutt, J.A., Rein, K., Boggs, S.E., Barr, E.B., and Fleming, L.E., 2005, The toxicity of microcystin LR in mice following 7 days of inhalation exposure: Toxicon, v. 45, issue 6, p. 691-698.

Chorus, I., Bartram, J., ed, 1999, Toxic cyanobacteria in water: A guide to their public health consequences, monitoring and management: Spon Press, London, chap. 3, 4, 5, and 12.

Cong, L., Huang, B., Chen, Q., Lu, B., Zhang, J., and Ren, Y., 2006, Determination of trace amount of microcystins in water samples using liquid chromatography coupled with triple quadrupole mass spectrometry: Analytica Chimica Acta, v. 569 , p. $157-168$.

Dahlmann, J., Budakowski, W.R., and Luckas, B., 2003, Liquid chromatography-electrospray ionization-mass spectrometry based method for the simultaneous determination of algal and cyanobacterial toxins in phytoplankton from marine waters and lakes followed by tentative structural elucidation of microcystins: Journal of Chromatography A, v. 994 , p. $45-57$.

Dawson, R.M., 1998, Review article: The toxicology of microcystins: Toxicon, v. 36, p. 953-962.

Dell' Aversano, C., Eaglesham, G.K., and Quilliam, M.A., 2004, Analysis of cyanobacterial toxins by hydrophilic interaction liquid chromatography-mass spectrometry: Journal of Chromatography A, v. 1028, p. 155-164.

Fastner, J., Flieger, I., and Neumann, U., 1998, Technical note: Optimised extraction of microcystins from field samples-A comparison of different solvents and procedures: Water Research, v. 32, p. 3,177-3,181.
Graham, J.L., Loftin, K.A., Ziegler, A.C., and Meyer, M.T., 2008 , Guidelines for design and sampling for cyanobacterial toxin and taste-and-odor studies in lakes and reservoirs: U.S. Geological Survey Scientific Investigations Report 2008-5038, 39 p.

Jacquet, C., Thermes, V., de Luze, A., Puiseux-Dao, S., Bernard, C., Joly, J.-S., Bourrat, F., and Edery, M., 2004, Effects of microcystin-LR on development of medaka fish embryos (Oryzias latipes): Toxicon, v. 43, p. 141-147.

Lahti, K., Rapala, J., Färdig, M., Niemelä, M., and Sivonen, K., 1997, Persistence of cyanobacterial hepatotoxin, microcystin-LR in particulate material and dissolved in lake water: Water Research, v. 31, p. 1,005-1,012.

Lawton, L.A., Edwards, C., Beattie, K.A., Pleasance, S., Dear, G.J., and Codd, G.A., 1995, Isolation and characterization of microcystins from laboratory cultures and environmental samples of Microcystis aeruginosa and from an associated animal toxicosis: Natural Toxins, v. 3, p. 50-57.

Li, X.-Y., Chung, I.-K., Kim, J.-I., and Lee, J.-A., 2004, Subchronic oral toxicity of microcystin in common carp (Cyprinus carpio L.) exposed to Microcystis under laboratory conditions: Toxicon, v. 44, p. 821-827.

Milutinović, A., Živin, M., Zorc-Pleskovič, R., Sedmak, B., and Šuput, D., 2003, Nephrotoxic effects of chronic administration of microcystins -LR and -YR: Toxicon, v. 42, p. $281-288$.

Orr, P.T., Jones, G.J., Hunter, R.A., and Berger, K., 2003, Exposure of beef cattle to sub-clinical doses of Microcystis aeruginosa: toxin bioaccumulation, physiological effects and human health risk assessment: Toxicon, v. 41, p. 613-620.

Orr, P.T., Jones, G.J., Hunter, R.A., Berger, K., De Paoli, D.A., and Orr, C.L.A., 2001, Ingestion of toxic Microcystis aeruginosa by dairy cattle and the implications for microcystin contamination of milk: Toxicon, v. 39, p. 1,847-1,854.

Sangolkar, L.N., Maske, S.S., and Chakrabarti, T., 2006, Review-methods for determining microcystins (peptide hepatotoxins) and microcystins-producing cyanobacteria: Water Research, v. 40, p. 3,485-3,496.

Skoog, D.A., West, D.M., and Holler, F.J., ed., 1996, Fundamentals of analytical chemistry: Saunders College Publishing, Fort Worth, table 4.2, p. 50.

Spoof, L., Vesterkvist, P., Lindholm, T., and Meriluoto, J., 2003, Screening for cyanobacterial hepatotoxins, microcystins and nodularin in environmental water samples by reversed-phase liquid chromatography-electrospray ionization mass spectrometry: Journal of Chromatography A, v. 1020 , p. $105-119$. 
Tsuji, K., Naito, S., Kondo, F., Watanabe, M.F., Suzuki, S., Nakazawa, H., Suzuki, M., Shimada, T., and Harada, K.-I., 1994, A clean-up method for analysis of trace amounts of microcystins in lake water: Toxicon, v. 32, p. 1,251-1,259.

Wehr, J.D., and Sheath, R.G., 2003, Freshwater algae of North America, ecology and classification: Academic Press, p. 918.
Whereat, E.B., Farrell, J.G., and Humphries, E.M., 2004, Volunteer phytoplankton monitoring in the inland bays of Delaware, USA., in Steidinger, K.A., Landsberg, J.H., Tomas, C.R., Vargo, G.A., eds, Harmful algae 2002, Florida Fish and Wildlife Conservation Commission, Florida Institute of Oceanography, and International Oceanographic Commission of UNESCO, St. Petersburg, Florida, p. 367-368. 
Publishing support provided by: Rolla Publishing Service Center

For more information concerning this publication, contact: Director, USGS Kansas Water Science Center 4821 Quail Crest Place

Lawrence, KS 66049

(785) 842-9909

Or visit the Kansas Water Science Center Web site at: http://ks.water.usgs.gov 
Back cover. Top and bottom photographs show mallard ducks swimming in water with substantial cyanobacterial accumulations in Silver Lake, Dover, Delaware, September 2007. Middle photograph shows cyanobacterial accumulations in Silver Lake, Dover, Delaware, dominated by Anabaena sp., Cylindrospermospis sp., and Microcystis sp., September 2007 (photographs taken by Robin Tyler, Delaware Department of Natural Resources and Environmental Control Division of Water Resources Environmental Laboratory). 


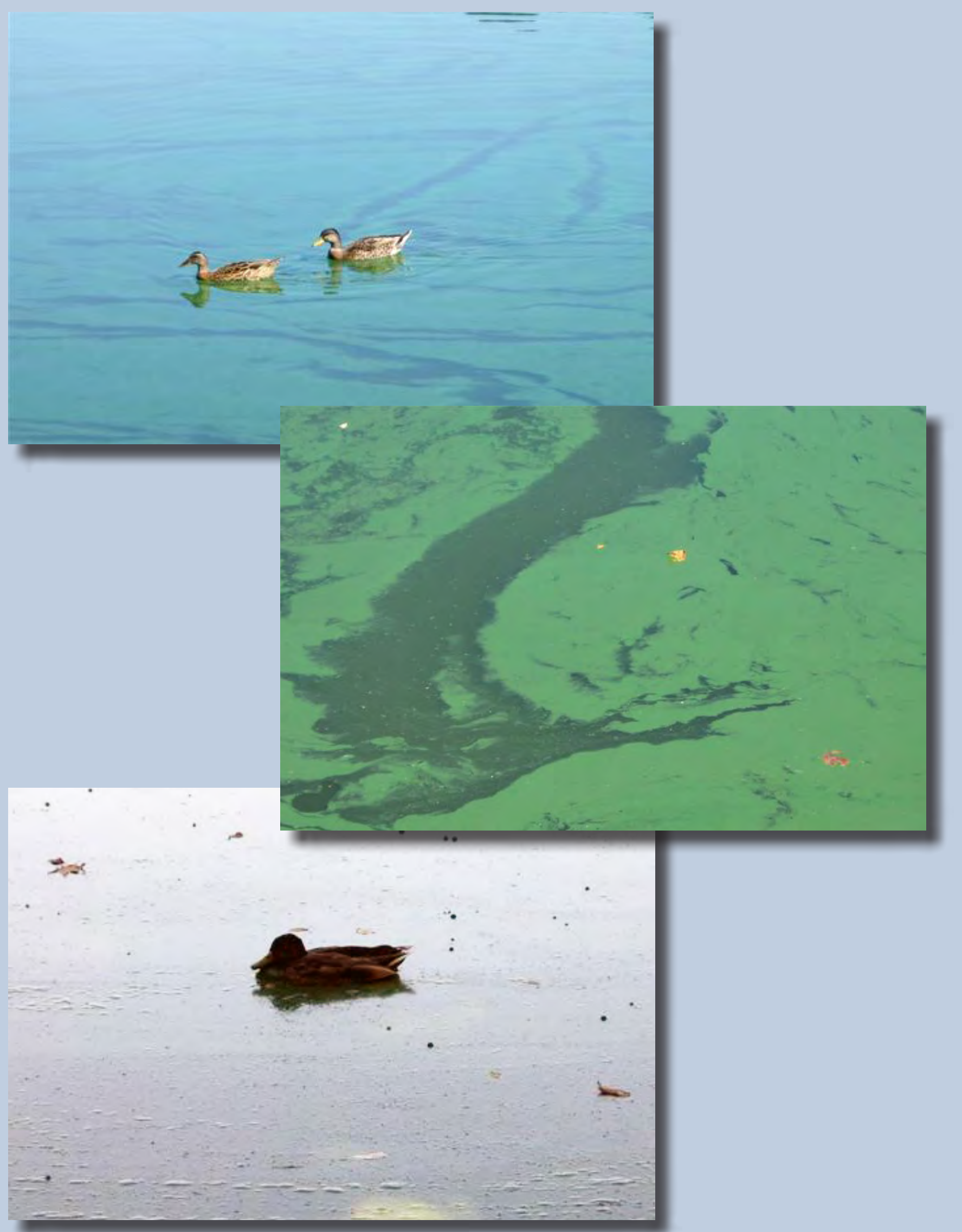

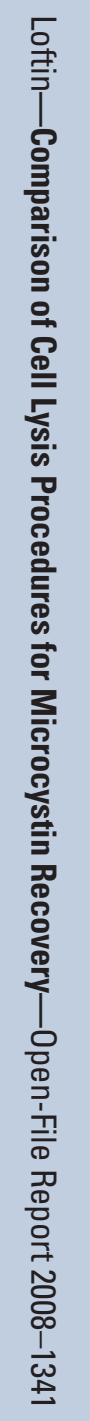

